\title{
PENERAPAN E-OFFICE DALAM UPAYA PENINGKATAN KINERJA BISNIS PERUSAHAAN
}

\author{
Nada Nur Izzati ${ }^{1)}$, Marsofiyati ${ }^{2)}$ \\ 1,2 Program Studi S1Pendidikan Administrasi Perkantoran, Universitas Negeri Jakarta \\ e-mail : nadaizzati28@gmail.com, marsofiyati@unj.ac.id
}

\begin{abstract}
Abstrak
Administrasi perkantoran memiliki peranan yang sangat penting. Sebagian besar kegiatan perkantoran telah enggunakan aplikasi e-office. E-office kini menjadi tren yang sulit dipisahkan dari kegiatan perkantoran. Tren tersebut akhirnya berdampak pada peningkatan kinerja bisnis perusahaan yang berjalan secara efektif dan efisien. Penulisan ini membahas mengenai penerapan e-office dalam perusahaan. Adapun yang menjadi tujuan penulisan ini adalah untuk mengetahui gambaran dan menganalisa penerapan e-office dalam upaya peningkatan kinerja bisnis perusahaan.
\end{abstract}

Kata kunci: Administrasi Perkantoran, E-office, Peningkatan Kinerja Bisnis

\section{PENDAHULUAN}

Indonesia saat ini sedang memasuki era industri baru yang disebut dengan era revolusi industri 4.0. Arti 4.0 sendiri adalah bahwa revolusi industri ini telah memasuki gelombang ke-4 dari perkembangan industri yang berbeda dari sebelumnya.

Dasar kemunculan era revolusi industri 4.0 ini dapat dilihat dari berubahnya cara kerja manusia akibat dari besarnya peran internet dalam otomatisasi atau digitalisasi di berbagai sektor kehidupan. Hampir semua sektor kehidupan manusia memakai internet, sebut saja e-banking, e-commerce, $e$ - government, e-learning, e-library, dan lain sebagainya. Semuanya sudah terhubung dengan internet atau dapat disebut dengan Internet of Things (IOT).

Perkembangan teknologi informasi dan komunikasi yang semakin pesat mengakibatkan organisasi pemerintah maupun swasta dan perusahaan-perusahaan yang ingin memaksimalkan penggunakan teknologi otomatisasi dengan cara memanfaatkan teknologi yang ada dan sedang berkembang, baik untuk berkomunikasi dengan banyak orang, untuk pemberian informasi, maupun 
untuk keperluan administrasi perkantoran, seperti dalam proses pengarsipan, dokumentasi dan surat menyurat yang sering dilakukan dalam lingkungan perkantoran.

Electronic Office (e-office) adalah suatu sistem yang berhubungan dengan administrasi yang secara maya memusatkan komponen-komponen sebuah organisasi, di mana data, informasi dan komunikasi dibuat melalui media telekomunikasi. Seiring perkembangan zaman serta dengan kebijakan penerapan reformasi birokrasi di Indonesia yang mewajibkan setiap proses bisnis atau kegiatan kantor harus berjalan dengan efisien dan efektif yang menyebabkan terjadinya transformasi proses bisnis dari sistem konvensional atau manual ke sistem otomatisasi. Proses bisnis yang dilakukan secara manual (document driven) menggambarkan pengiriman sebuah dokumen, misalnya surat yang masih berupa hardcopy, dan dikirimkan dengan kurir antar unit di lingkungan kantor (Arief, 2005). Eoffice sebagai salah satu hasil dari pekembangan teknologi tentunya akan membantu pegawai di kantor dalam menyelesaikan tugas-tugas mereka. Tidak hanya pegawai, tetapi para pemimpin pun juga akan ikut menikmati hasilnya misalnya menghasilkan laporan yang dapat digenerate dengan cepat berdasarkan data terpadu yang ada didalam sistem e-office. Sistem e-office mempermudah penyimpanan dan pengolahan data di dalam suatu kantor karena data menjadi terpusat (centralized) dengan bantuan database sehingga data yang ada akan saling terhubung dan menjadi kesatuan utuh yang dapat memberikan informasi bagi pegawai kantor. Selain data tentunya penggunaan komputer bagi para pegawai juga mutlak diperlukan demi terciptanya sistem e-office (Oktaf \& Hendrixon, 2017).

Penerapan sistem e-office diharapkan memberikan banyak manfaat terhadap peningkatan efektivitas kegiatan korespondensi kedinasan, akan tetapi sistem e- office merupakan karya tangan manusia sehingga penerapannya masih terdapat beberapa kekurangan, berdasarkan hasil wawancara dengan Ibu Nurul Badriyah kekurangan tersebut diantaranya seperti koneksi atau jaringan yang tidak stabil, kesalahan penulisan saat memasukkan data surat ke dalam data base e-office seperti penomoran surat, tanggal surat, tujuan surat, isi surat, dan jenis surat sehingga terjadi keterlambatan penyelesaian surat serta belum adanya kesadaran penerima e-office terhadap penggunaan internet yang masih rendah. Berdasarkan banyaknya kelemahan tersebut Fakultas Ekonomi Universitas Negeri Surabaya berupaya sebaik mungkin untuk 
memperbaikinya, sehingga tujuan diterapkannya sistem e-office dapat terwujud. Fakta dan fenomena yang sudah dijelaskan di atas menunjukkan bahwa penerapan e-office merupakan upaya pemerintah dalam memanfaatkan teknologi informasi dan komunikasi untuk memfasilitasi pengelolaan korespondensi kedinasan. Banyaknya surat yang dikelola dan perlunya pengiriman surat dengan tepat dan cepat dalam kegiatan korespondensi kedinasan menjadikan teknologi informasi sebagai media yang dianggap mampu dan handal untuk membantu dalam pengelolaan surat dan pengiriman surat yang cepat dan tepat.

Berdasarkan latar belakang yang ada, penulis mengambil judul "Penerapan Eoffice dalam Upaya Peningkatan Kinerja Bisnis Perusahaan"

\section{RUMUSAN MASALAH}

Rumusan masalah dalam penulisan artikel jurnal ini yaitu penerapan e-office yang dapat digunakan sebagai upaya untuk meningkatkan kinerja bisnis perusahaan.

\section{TINJAUAN PUSTAKA}

Menurut Dewandaru (2013), semenjak bergulirnya masa reformasi di Indonesia, seluruh kegiatan pemerintahan mengalami transformasi yang dikenal dengan nama reformasi birokrasi. Salah satu program reformasi adalah penerapan electronic government (e-government) di lingkungan perkantoran pemerintah. Dalam egovernment dikenal sebuah layanan untuk mendukung kegiatan perkantoran khususnya administrasi dengan nama e-perkantoran (eoffice). Penelitian yang dilakukan menghasilkan indikator keberhasilan yang menampilkan data perbandingan kondisi sebelum dan sesudah pemanfaatan aplikasi eoffice di Pusjatan. Pemanfaatan aplikasi eoffice terbukti sangat membantu dalam mempercepat proses bisnis perkantoran.

Menurut Mulyono (2018), elektronik office (e-office) sebagai salah satu hasil dari perkembangan teknologi tentunya akan membantu pegawai di kantor dalam menyelesaikan tugas-tugas perkantoran. Tidak hanya pegawai, tetapi para pemimpin pun juga akan ikut menikmati hasilnya sehingga dapat menghasilkan laporan yang dapat di-generate dengan cepat berdasarkan data terpadu yang ada di dalam sistem eoffice. Hasil penelitian menunjukkan bahwa aplikasi e-office berupa surat masuk dan surat keluar serta disposisi memudahkan pegawai mengurus administrasi perkantoran khususnya dokumen persuratan dan 
korespondensi sehingga surat dapat diproses secara cepat dan efisien.

Menurut Juariyah dan Hendrixon (2017), salah satu cara untuk memperluas internal organisasi yaitu dengan menggunakan elektronik office (e-office). Aplikasi e-office berupa disposisi online yang memudahkan karyawan mengurus administrasi perkantoran khususnya surat masuk, sehingga surat dapat diproses secara cepat dan efisien.

\section{HASIL DAN PEMBAHASAN}

Dalam pembahasan ini difokuskan ke dalam penerapan e-office dalam upaya peningkatan kinerja bisnis perusahaan. Electronic Office (e-office) adalah suatu sistem yang berhubungan dengan administrasi, secara maya memusatkan komponen-komponen sebuah organisasi dimana data, informasi, dan komunikasi dibuat melalui media telekomunikasi (Robles, 2001). Electronic dalam E-Office dapat berarti bahwa semua pekerjaan yang berhubungan dengan administrasi perkantoran dikerjakan secara elektronis dan menggunakan bantuan alat komunikasi dan sistem informasi. Dengan perkembangan teknologi telekomunikasi saat ini, jaringan broadband berkecepatan tinggi, dan internet, maka perkantoran telah menjadi elektronis secara elektronik. Pekerjaan kantor yang selama beberapa dekade dilakukan secara manual telah berubah menjadi elektronik bahkan beberapa sudah menerapkan kantor maya. Kantor elektronis menggunakan teknologi komunikasi untuk menyediakan layanan administrasi perkantoran secara elektronis kepada siapa saja, dimana saja

Salah satu pekerjaan administrasi perkantoran adalah korespondensi. Perbedaan antara e-office dengan korespondensi kedinasan manual adalah peralatan dan perlengkapan serta media yang digunakan untuk mendukung penerapan yang dilakukan (Dewandaru, 2013). Korespondensi kedinasan manual indentik dengan pemakaian kertas sebagai media untuk mencatat surat masuk, surat keluar dan penyimpanan surat secara manual. Sedangkan e-office menggunakan sistem peralatan dan perlengkapan mesin-mesin elektronik, seperti seperangkat komputer, seperangkat server, seperangkat aplikasi untuk memasukkan surat masuk, surat keluar dan penyimpanan surat yang berbasis sistem informasi yang terhubung secara online sehingga seluruh data surat atau informasi yang dibutuhkan dapat diakses dengan mudah dan cepat. Selain itu korespondensi kedinasan manual memiliki tingkat keawetan yang kurang dan membutuhkan banyak ruang 
dalam menyimpan data-data surat sehingga akan menyulitkan ketika penemuan kembali saat surat-surat sedang dibutuhkan. Sedangkan e-office memiliki tingkat keawetan yang jauh lebih baik dan mampu mengurangi penggunaan tempat penyimpanan surat karena semua sudah tercover di dalam e-office ini.

\section{KESIMPULAN DAN SARAN}

Saat ini dunia sudah memasuki era industri baru, yakni revolusi industri 4.0 atau yang biasa dikenal dengan 4IR. 4IR mencakup beragam teknologi canggih, seperti kecerdasan buatan (AI), Internet of Things (IoT), wearables devices, robotika canggih, dan 3D printing. Perkembangan teknologi yang sangat pesat tentu saja akan berpengaruh pada kehidupan manusia. Agar kita dapat menjadi sumber daya manusia yang berkualitas tentu saja kita harus dapat menyesuaikan diri dengan perkembangan teknologi ini.

Penerapan e-office dalam kegiatan administrasi perkantoran mampu mendukung terciptanya tertib administrasi perkantoran khususnya dalam kegiatan korespondensi. EOffice merupakan suatu layanan berupa aplikasi elektronik yang memanfaatkan teknologi informasi dan komunikasi untuk memfasilitasi pengolahan administrasi perkantoran yaitu korespondensi kedinasan berupa surat menyurat baik surat masuk, surat keluar dan penyimpanan surat, bagi setiap pegawai di suatu perusahaan atau institusi yang dilakukan secara elektronik Tujuan dalam penerapan e-office ini adalah untuk meningkatkan efektivitas kegiatan perkantoran khususnya kegiatan korespondensi kedinasan dari yang sebelumnya manual menjadi elektronik.

Pemanfaatan aplikasi e-office terbukti sangat membantu dalam mempercepat proses bisnis perkantoran. E-office yang telah memberikan implikasi terhadap; a. Kecepatan transfer dokumen perkantoran antar unit b. Penghematan terhadap pemakaian ATK. c. Mereduksi kebutuhan tenaga kerja terkait distribusi dokumen perkantoran. d. Kecepatan dalam pengambilan keputusan oleh pimpinan.

\section{DAFTAR PUSTAKA}

Dewandaru, D. S. (2013). Pemanfaatan Aplikasi E-office Untuk Mendukung Reformasi Birokrasi Studi Kasus: Pusjatan.

Juairiyah, O., \& Hendrixon. (2017). Penerapan E-Office dalam Administrasi Perkantoran.

Mulyono, T. (2018). Sistem Informasi E-office sebagai Pendukung Program Paperless Korespondensi Perkantoran.

Robles, M. (2001). The e-Office: What Exactly it is? Office Solutions; Mt Airy, 43-45. 
